\title{
Hypothesis on the genesis of the Golfo Corcovado submarine platform, Northern Patagonia
}

\author{
José F. Araya Vergara ${ }^{1}$ jaraya@uchilefau.cl
}

\begin{abstract}
The purpose of this work is to found a hypothesis on the origin of the submarine flattened surface of Golfo Corcovado, considered as a submerged landform. This submarine landform was surveyed by means of sub bottom profiler records obtained on board of the AGOR Vidal Gormaz research vessel. The procured acoustic features can be homologated with similar structures interpreted as submerged weathering mantles in other sea bottoms of the world. All together, the superficial zone of the deep weathering mantle of sub-aerial etchplains shows comparable elements that can be identified in the studied sub bottom. In order to understand the process of submersion, both the tectonic control and the age of the deep weathering were taken into account. So, the following consequents of hypothesis are exposed: a) the space between the bottom and sub bottom reflectors of Corcovado can be interpreted as regolith of basement and the sub bottom reflector, as the corresponding weathering front; $b$ ) its sinking seems related with the regional system of faults; c) the Miocene age of the sub aerial weathering exposure lapse indicates that the corresponding mantle pre-dates the etchplain submersion and that, therefore, the sub-bottom features represent a submerged etchplain surface; and d) a fundamental problem is the lack of total stripping of the weathering mantle during the submersion; the corresponding response can be given only after the knowledge of some complex processes, exposed succinctly in the discussion.
\end{abstract}

Keywords: submarine landforms, submerged etchplain, morpho-acoustic analysis, submersion processes.

\section{Hipótesis sobre la génesis de la plataforma submarina del Golfo Corcovado, Norpatagonia}

\section{RESUMEN}

El propósito de este trabajo es fundamentar una hipótesis sobre el origen de la superficie aplanada submarina de Golfo Corcovado, considerada como una forma sumergida. Esta forma submarina fue levantada mediante registros de perfilador de sub-fondo obtenidos a bordo del buque de investigación AGOR Vidal Gormaz. Los rasgos acústicos detectados pueden ser homologados con estructuras similares, interpretadas como mantos de meteorización sumergidos en otros fondos marinos del mundo. Conjuntamente, la zona superficial del manto de meteorización de etchplains sub-aéreas muestra elementos comparables a los que pueden ser identificados en el sub-fondo estudiado. Para comprender el proceso de sumersión, tanto el control tectónico como la edad de la meteorización profunda han sido tomados en cuenta. Así, puede indicarse los siguientes consecuentes de hipótesis: a) el espacio entre los reflectores de fondo y sub-fondo de Corcovado puede ser interpretado como regolito de basamento y el reflector de sub-fondo, como el frente de meteorización correspondiente; b) su sumersión parece relacionada con el sistema regional de fallas; c) la edad miocena de la exposición sub-aérea de la meteorización, indica que el manto correspondiente pre data la sumersión de la etchplain y que, consecuentemente, los rasgos de sub-fondo representan una superficie sumergida; y d) un problema fundamental es la falta de remoción total del manto de meteorización durante la sumersión; la respuesta correspondiente puede obtenerse sólo conociendo algunos procesos complejos expuesto brevemente en la discusión.

Palabras clave: formas submarinas, etchplain sumergida, análisis morpho-acústico, procesos de sumersión.

Recibido el 30 de noviembre de 2012, aceptado el 15 de diciembre de 2012.

1 Departamento de Geografía, Universidad de Chile, Portugal 084, Santiago, R.M, Chile. 


\section{INTRODUCTION}

The first observations on the surface of the submarine platform of Golfo Corcovado were carried out in the general context of the Patagonian fjords and channels (ARAYA-VERGARA 1997 and 2008). Also, a topographic survey was carried through by RODRIGO (2008). The submarine longitudinal depression shows here characteristics of a sunken block of basement platform, related possibly with the regional system of faults, studied by several authors, according to the compilation of DELGADO (2004). Its structure is related with the presence or absence of confluent fjords in the coast (Fig. 1). In front of confluent fjords, the bottom of the depression is dissected and deeper. On the contrary, in absence of confluent fjords, it is not dissected and shallow (bottom depths between 100 and $200 \mathrm{~m}$ ) and contains in its sub bottom a possible mantle of weathering. More recent researches on sub aerial surfaces of coastal etchplains indicate that their thick drapes of deep weathering have relationship with the process of flattening on them (ARAYA-VERGARA 2000).

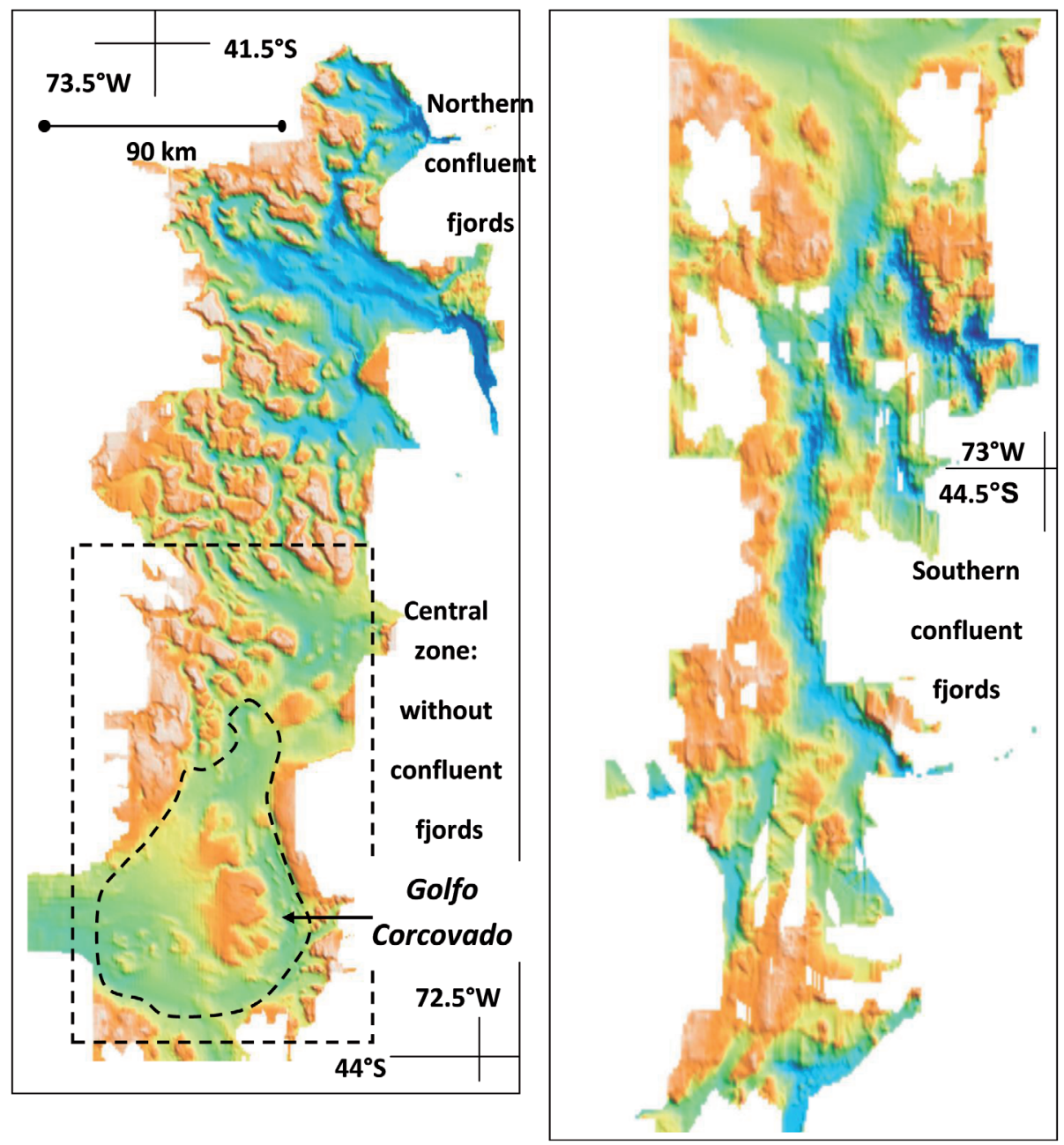

Fig. 1. Golfo Corcovado region; zoning and location; submarine topography surveyed by Rodrigo (2008): blue zones = greatest depths; green zone $=$ smallest platform depths.

Fig. 1. Región de Golfo Corcovado: zonación y localización; topografía submarina levantada por Rodrigo (2008); zonas azules = mayores profundidades; zona verde = plataforma de profundidades menores. 
Starting from a better knowledge of the regional coastal surfaces with features of deep weathering, which reach the Chiloé island, the purpose of the present work is the formulation of a hypothesis on the origin of some submarine flattened surfaces. The case of Corcovado platform is a good example for this task.

\section{MATERIALS AND METHODS}

The submarine platform of Corcovado Gulf (Fig. 2) shows clear accordance of summit levels and lack of acoustically recognizable sedimentary cover. In exchange, an acoustic feature indicates different level of acoustic impedance below the bottom, showing a sub bottom reflector. Observations of sub aerial etchplain surfaces between Central Chile and Chiloé (ARAYA-VERGARA 2000) suggest that the acoustic structures of the Corcovado bottom can be compared with these superficial landforms of etchplain.

The submarine landforms were surveyed by mean of sub bottom profiler record $(3.5 \mathrm{kHz})$ obtained on board of the oceanographic ship AGOR Vidal Gormaz. For the analysis was used the systematics of DAMUTH (1978) and PRATSON \& LAINE (1989) on echo characters. The original records were photographed and processed with the Microsoft Office Publisher 2007, reaching better bright and contrasts levels for an improved observation. In order to compare the submarine echograms with sub-aerial surfaces of etchplain, different sections of exposed regolith were analysed, distinguishing the zones intracutaneous, subcutaneous and the weathering front in granitic rocks, gneiss and schists.

\section{RESULTS}

\section{Acoustic features}

The profile of the oceanographic section shows two types of platform: without important dissection in the central part (Fig. 2, upper echogram, with insets $\mathrm{A}$ and $\mathrm{B}$ ); and with dissection toward the SW from the central part (Fig. 2, lower echogram). The Table 1 contains the specifications of these two types of morphology. The more evident difference is observed in the type accordance of summit levels, in the vertical distribution of the acoustic features and in the depth ranks observed for each type. The flattened surface in A and B is almost intact and shows below the basement a sub bottom reflector; in exchange the dissected surface lacks of this feature. Nevertheless, both cases show accordance of summit levels. 


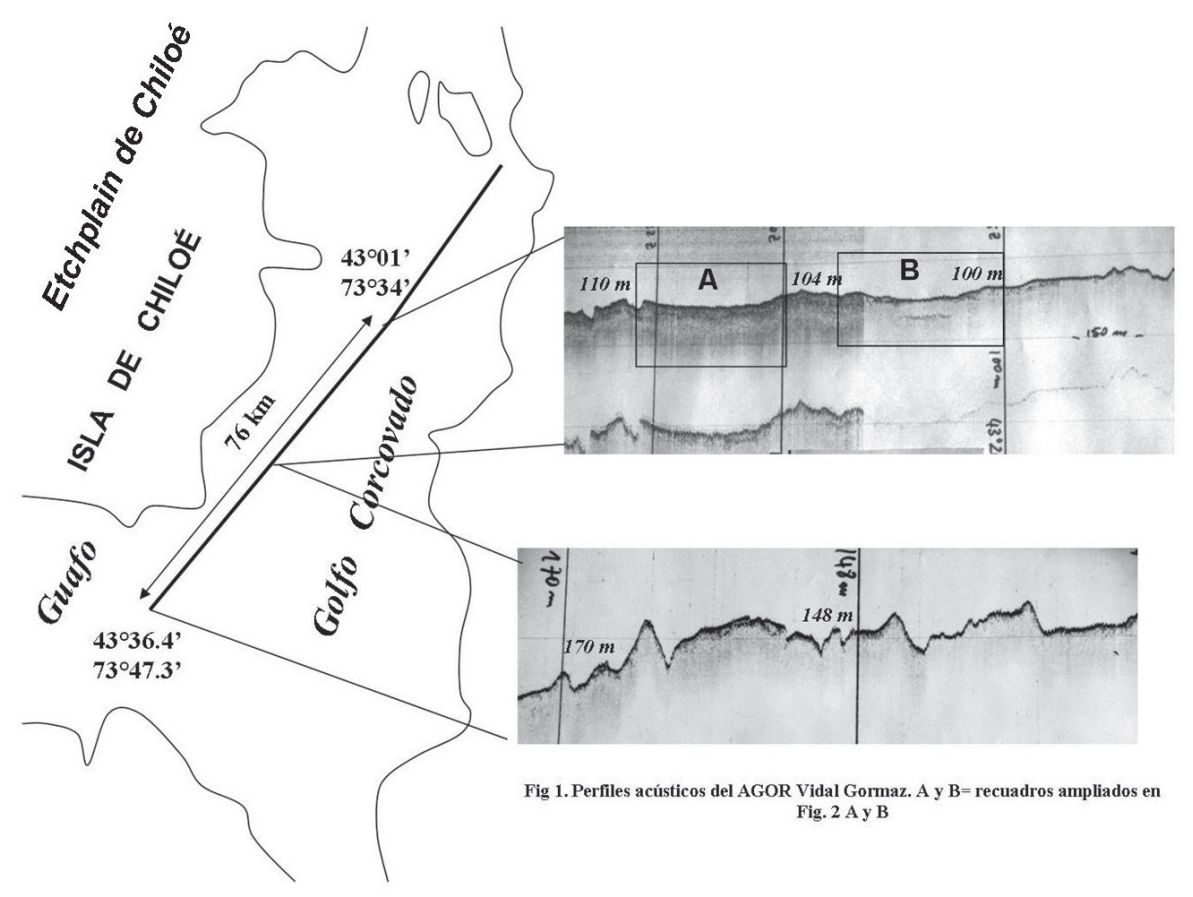

Fig. 2. AGOR Vidal Gormaz, acoustic profiles. A and B = enlarged insets in Fig. 3 A and B.

Fig. 2. Perfiles acústicos del AGOR Vidal Gormaz. A y B = recuadros ampliados en Fig. 3 A y B.

Table 1. Morphological tyPes and aCOUSTIC features in the Profiles OF The Fig. 2

Tabla 1. Tipos morfológicos y Rasgos aCÚsticos En los Perfiles de la Fig. 2

\begin{tabular}{|c|c|c|c|c|}
\hline Platform zone & $\begin{array}{c}\text { Type of } \\
\text { accordance } \\
\text { summit levels }\end{array}$ & $\begin{array}{c}\text { Summits and } \\
\text { depressions depths } \\
\text { (m) }\end{array}$ & $\begin{array}{c}\text { Echo character, after } \\
\text { system of Damuth } \\
\text { (1978) and Pratson \& } \\
\text { Laine (1989) }\end{array}$ & Denomination \\
\hline $\begin{array}{c}\text { Flattened, } \\
\text { nearly intact, } \\
\text { without important } \\
\text { dissection; upper } \\
\text { profile Fig } 2 \\
\text { (central zone) }\end{array}$ & $\begin{array}{c}\text { Small depth } \\
\text { differences } \\
\text { among summits } \\
\text { and depressions }\end{array}$ & $\begin{array}{c}\text { Summits }=100-104 \\
\text { Depressions }= \\
110-120\end{array}$ & $\begin{array}{c}\text { Terraced echoes; } \\
\text { high difference } \\
\text { between bottom and } \\
\text { sub bottom echoes; } \\
\text { indistinct, prolonged } \\
\text { and semiprolonged } \\
\text { echoes }\end{array}$ & $\begin{array}{c}\text { Flattened, } \\
\text { almost intact } \\
\text { surface }\end{array}$ \\
\hline $\begin{array}{l}\text { With important } \\
\text { dissection; lower } \\
\text { profile Fig.2 (SW } \\
\text { zone) }\end{array}$ & $\begin{array}{c}\text { Evident depth } \\
\text { differences } \\
\text { among summits } \\
\text { and depressions }\end{array}$ & $\begin{array}{c}\text { Summits }=140-150 \\
\text { Depressions }= \\
160-170\end{array}$ & $\begin{array}{c}\text { Some irregular } \\
\text { hyperbolae features; } \\
\text { one bottom reflector; } \\
\text { indistinct and } \\
\text { semiprolonged echo. }\end{array}$ & $\begin{array}{c}\text { Dissected } \\
\text { surface }\end{array}$ \\
\hline
\end{tabular}


Flattened, nearly intact platform

The corresponding bottom reflector ( Fig. 3 and Table 2) indicates the existence of a smooth basement surface. All together, the sub bottom faint reflector shows an irregular and very undulating sub bottom surface. Between the bottom and sub bottom basements, the space inter reflectors indicates material of nearly low consistence, as evidenced by the impedance change between this zone and the reflectors above and below. No acoustic feature of sedimentary structure is observed here.

TAble 2. ACOUSTIC PRECisions ON THE Flattened, NEARLy INTACT PLATFORM

Tabla 2. Precisiones acústicas sobre la plataforma aplanada, CaSi intacta

\begin{tabular}{|c|c|c|c|c|}
\hline $\begin{array}{l}\text { Units } A \text { and } B \text {, } \\
\text { Fig. } 3\end{array}$ & $\begin{array}{l}\text { Acoustic character } \\
\text { of the bottom } \\
\text { reflector }\end{array}$ & $\begin{array}{c}\text { Acoustic character } \\
\text { of the sub bottom } \\
\text { reflector }\end{array}$ & $\begin{array}{l}\text { Acoustic character } \\
\text { of the space inter } \\
\text { reflectors }\end{array}$ & $\begin{array}{l}\text { total thickness } \\
\text { of reflectors }(m)\end{array}$ \\
\hline A & $\begin{array}{l}\text { Indistinct and } \\
\text { prolonged strong } \\
\text { echo, } \\
\text { (thickness } \sim 15 \mathrm{~m} \text { ) }\end{array}$ & $\begin{array}{l}\text { Indistinct and } \\
\text { prolonged faint echo, } \\
\text { (thickness } \sim 15 \\
\text { m); relatively } \\
\text { discontinuous }\end{array}$ & $\begin{array}{l}\text { Semi transparent } \\
\text { (thickness 15-20 m) }\end{array}$ & $40-50$ \\
\hline B & $\begin{array}{l}\text { Indistinct and semi } \\
\text { prolonged strong } \\
\text { echo, (thickness } \\
\quad \sim 5 \mathrm{~m} \text { ) }\end{array}$ & $\begin{array}{l}\text { Indistinct and semi } \\
\text { prolonged faint echo, } \\
\text { (thickness } \sim 5 \\
\text { m); relatively } \\
\text { discontinuous }\end{array}$ & $\begin{array}{c}\text { Essentially } \\
\text { transparent } \\
\text { (thickness } 15-20 \mathrm{~m} \text { ) }\end{array}$ & $15-20$ \\
\hline
\end{tabular}



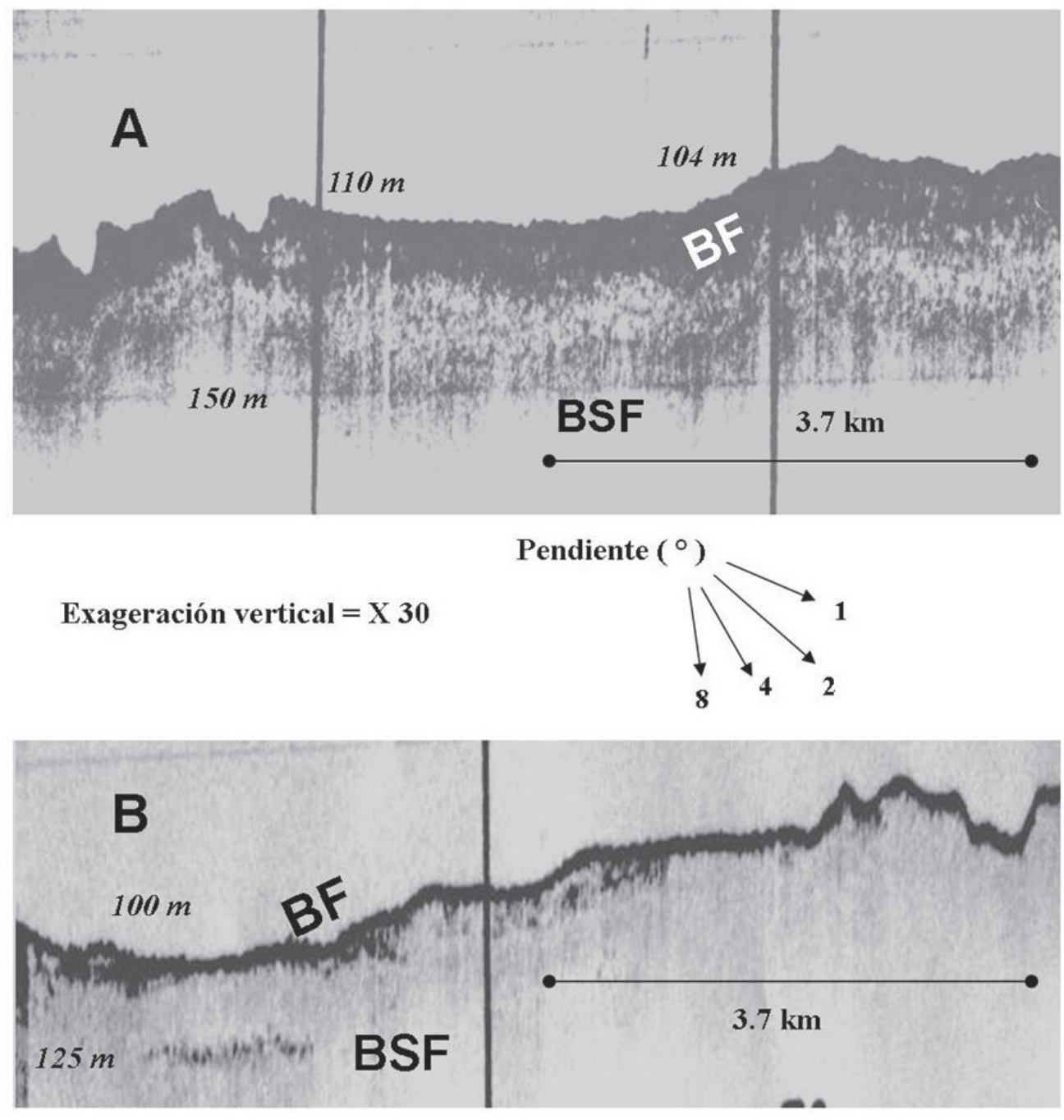

Fig. 3. Insets A and B in profiles of Fig. 2. Morphoacoustic features: BF = bottom basement; BSF = sub-bottom basement.

Fig. 3. Recuadros A y B en perfiles de Fig. 2. Rasgos morfoacústicos: $B F=$ basamento de fondo; BSF $=$ basamento de subfondo. 
Field experiences on sub aerial etchplains or Rumpffächen

In order to interpret the acoustic precisions shown in the Table 2, some experiences on sub aerial etchplains in Chile will be exposed.

In the Chiloé etchplain (Fig. 4), the flattening surface is elaborated on the foliated, schistose structure of the basement. Toward the surface, a regolith mantle is observed. It is composed by fine particles of the bedrock and relatively abundant schistose boulders of metrical dimensions. Some of them outcrop as exhumed elements. Starting from the weathering front, the thickness of the weathered mantle is of decametric dimension.

Jointly, in the coast range of Central Chile, the etchplain surface is elaborated principally on granitic rocks, gneisses, schistose bodies and volcanic rocks. But the crystalline basement gives the more typical weathered mantles, sometimes of unknown thickness (Fig. 5), produced by deep weathering. The more characteristic product of this process are the granitic or gneissic grus and spheroidal boulders. In some sectors, these boulders outcrop as exhumed bodies, but is the grus the material more commonly observed in the surfaces.

Both the Chiloé and the Central Chile etchplains indicate three parts near the surface of these landforms: from above to below, the surface of the relief, the possible weathering mantle and the probable weathering front (Figs. 4 and 5 A, B and C).

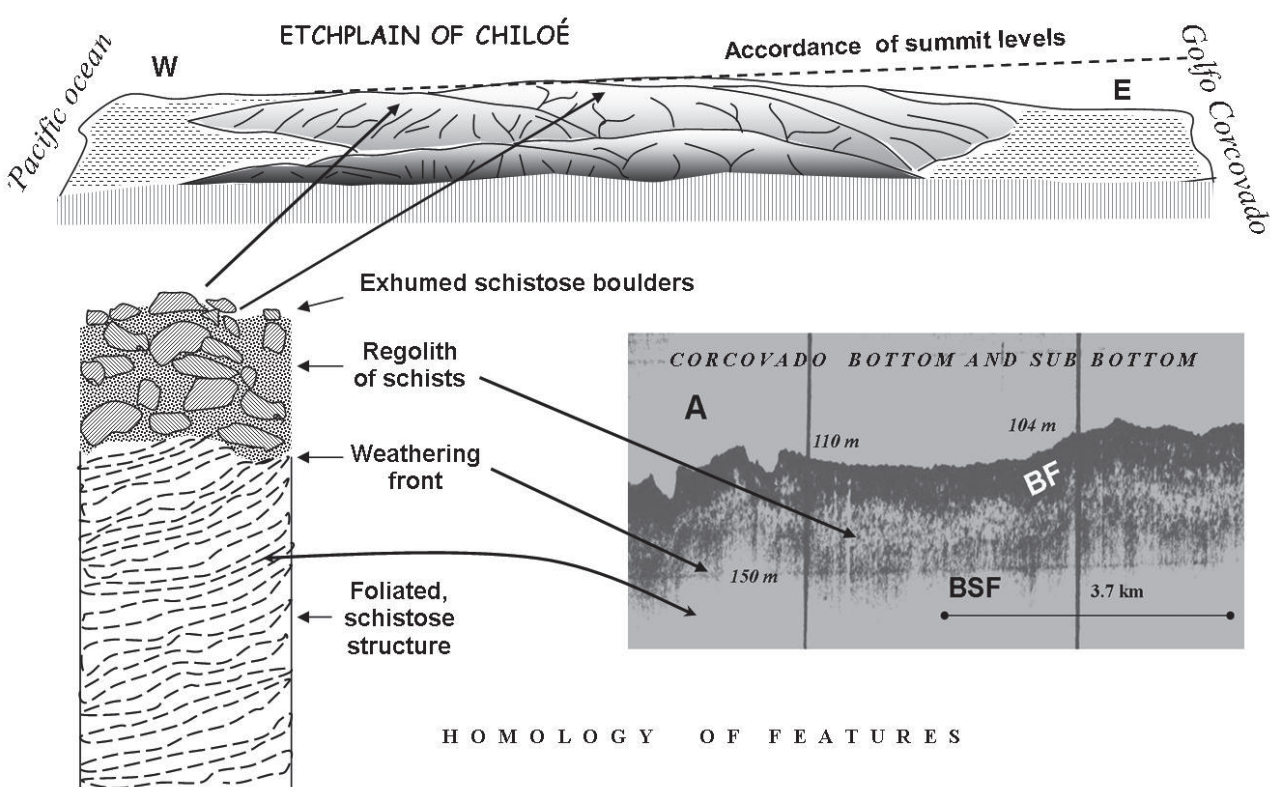

Fig. 4. Chiloé Island, Etchplain of Chiloé. Local character of the sub-aerial weathering mantle in the schistose etchplain, compared with the next Corcovado submarine platform. The thickness of the mantle is here decametric. The homology is only of features, not necessarily lithological.

Fig. 4. Isla de Chiloé, Etchplain de Chiloé. Carácter local del manto sub-aéreo de meteorización en la etchplain esquistosa, comparada con la plataforma submarina de Corcovado próxima. El espesor del manto es aquí decamétrico. La homología es solamente de rasgos, no necesariamente litológica. 

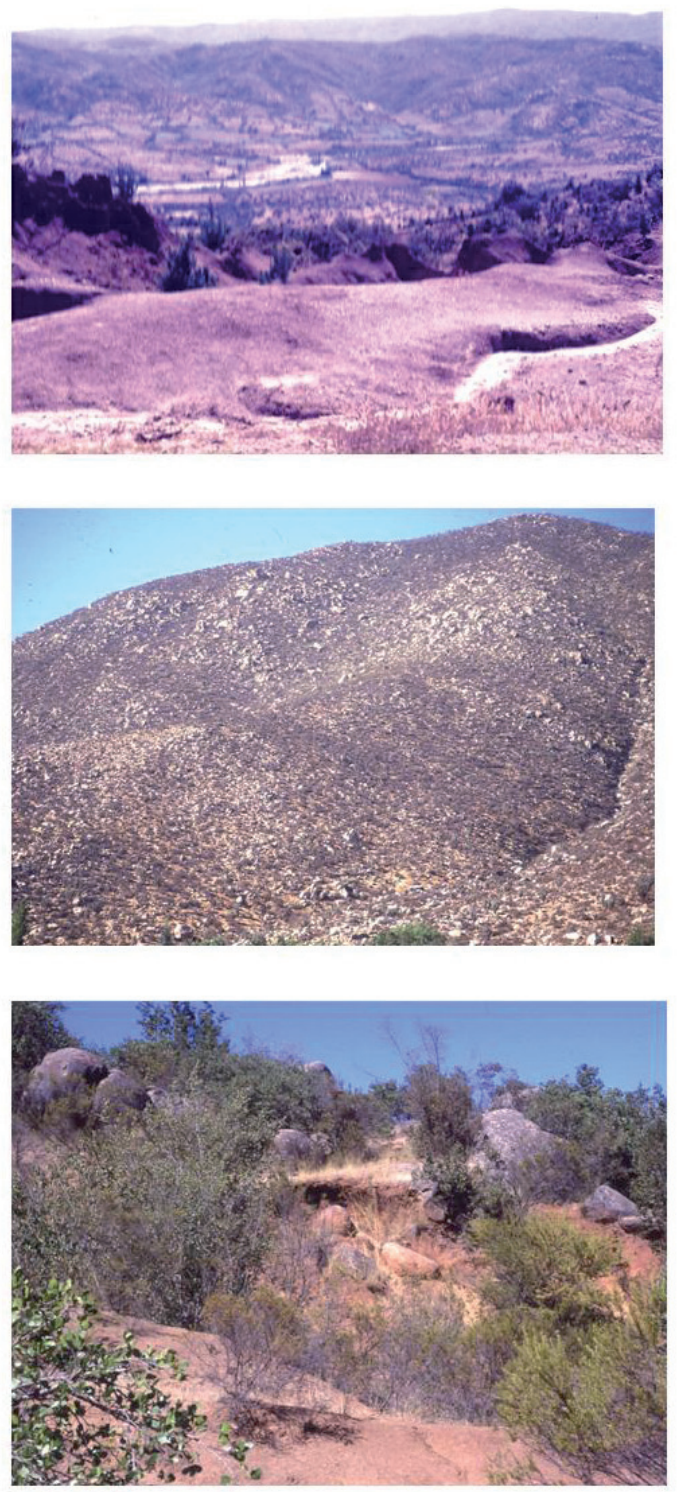

A: Maule region, Coipué $\left(35^{\circ} 15^{\circ} \mathrm{S}-72^{\circ}\right.$ $07^{\prime} \mathrm{W}$ ); dissected etchplain; foreground: slope with granitic and gneissic grus in the Coipué Surface (altitude 300-350 m); background: schistose Agua Buena Surface (altitude $\sim 500 \mathrm{~m}$ ) (Araya-Vergara 2000). A: Región del Maule $\left(35^{\circ} 15^{\prime} \mathrm{S}-72^{\circ} 07^{\prime} \mathrm{W}\right)$; etchplain disectada; primer plano: vertiente con grus granítico y gneissico en la Superficie Coipué (altitud 300-350 m); en lontananza: superficie esquistosa Agua Buena (altitud $\sim 500 \mathrm{~m}$ ) (Araya-Vergara 2000)

B: Salamanca $\left(\sim 31^{\circ} 50^{\prime} \mathrm{S}-70^{\circ} 58^{\prime} \mathrm{W}\right)$; abundant exhumed granitic boulders and tors, because of the grus removal. following a period of dominant stripping,

B: Salamanca ( $\left.31^{\circ} 50^{\circ} \mathrm{S}-70^{\circ} 58^{\prime} \mathrm{W}\right)$; abundantes bloques y tors graníticos exhumados, como consecuencia de la remoción del grus, siguiendo un período de denudación dominante.

C: Maule Region, Batuco $\left(35^{\circ} 18^{\prime} \mathrm{S}-71^{\circ}\right.$ $57^{\prime} \mathrm{W}$ ); granitic slope in dissected etchplain (Coipué Surface); exhumed and subterranean spheroidal boulders with grus, produced by differential deep weathering. C: Región del Maule, Batuco ( $35^{\circ} 18^{\prime} \mathrm{S}-$ $\left.71^{\circ} 57^{\prime} \mathrm{W}\right)$; vertiente granítica en etchplain disectado; bloques esferoidales exhumados y subterráneos con grus, producidos por meteorización profunda diferencial.

Fig. 5. General landscape types and characterisctic elements of partially stripped weathering mantles in Central Chile.

Fig. 5. Tipos generales de paisaje y elementos característicos de mantos de meteorización parcialmente removidos en Chile Central. 


\section{DISCUSSION}

\section{Regarding other submarine experiences}

Experiences in the coast of Bombay, India, indicate that a sub bottom reflector, below the basement surface, represents - possibly - the base of a mantle of weathered rock (BHATTACHARYA et al. 1987). The acoustic structure observed by these authors is similar to that found in Golfo Corcovado. Approximate features are analyzed by BROOKE et al. (2010) in the volcanic shelf of Lord Howe Is. (North of Tasman Sea), where sub bottom reflectors are prevalent in areas of unconsolidated materials, in sectors in which the acoustic signal penetrates the seabed. The deepest reflectors evidenced in these areas are discontinuous, several meters apart with a strong reflector near de surface, even though the structure of these echoes is not commented in this paper. Nevertheless, these acoustic features are similar to those found by BHATTACHARYA et al. (1987) and ARAYA-VERGARA (1997).

\section{Concerning other sub aerial experiences}

THOMAS (1994), regarding several former researches, defines an etchplain as a type of planation surface developed through the removal of saprolithic material from the surface of an older planation surface. So, the overall process of stripping off a regolith and exposal of an uneven basal surface of weathering is termed etchplanation. Therefore, in order to distinguish an etchplain or Rumpffläche surface, the knowledge of the following facts is necessary: age of the deep weathering, evolution of weathered landsurfaces and approximate sequence of stages of deep weathering and stripping, including the tectonic control (TAYLOR \& HOWARD 1998; DEMEK 2003). Moreover, the analysis of landform erosion in the preservation of weathering mantles is important, as evidenced by the observations in craton surfaces (GUNNELL et al. 2007).

\section{Age of the deep weathering and sub aerial flattened surfaces}

In order to date flattened surfaces, the compilation of DUMONT (1991) indicates that 30 to 60 millions years is the time needed for a general flattening, which suggests problems of dating. All together, the long sequence of weathering and stripping stages, some of them tectonically controlled, as evidenced by landsurfaces in Uganda (TAYLOR \& HOWARD 1998) or the Bohemian Massif (DEMEK 2003), suggests that any denomination referring to the geological column must be dismissed (DUMONT 1991). In exchange, this author suggests the use of appellations referring a regional occurrence; in Chile, for instance, Coipué Surface, Agua Buena Surface (ARAYA-VERGARA 2000) or Chiloé Etchplain. In Central Chile, the relative dating of the deep weathering determined by ARAYA-VERGARA (2000) indicates a Pre-Pliocene age for post stripping outcrops of the regolith. Consequently, the age of weathering is thought to be at least Miocene, if the analyses of TAYLOR \& HOWARD (1998), DEMEK (2003) and DUMONT (1991) are considered.

\section{Complexity of the process}

In order to interpret the related acoustic features as expression of sunken weathered surfaces, the observer must realize that in the global process can operate several associate morphogenetic mechanisms.

Firstly, the influence of landform erosion in the preservation of weathering mantles has been analyzed in craton surfaces (GUNNELL et al. 2007), the aspect of which can induce to interpretation mistakes. Secondly, realizing that have been studied sea levels and uplift rate from composite rheology in glacial isostatic adjustment modeling (VAN DER WAL et al. 2010), these influences can produce alterations on the observed surface. 
The complexity of the possible mechanism can be better understood following the observations, hypothesis and discussions on the evolution of a region assumed as similar to the studied here (LIDMARBERGSTRÖM \& BONOW 2009; NIELSEN et al. 2009).

\section{CONCLUSION}

Considering the facts indicated in this work, the following hypothesis is exposed:

If: a) the acoustic features found in Golfo Corcovado can be homologated with similar structures interpreted as weathering mantles in other sea bottoms of the world (BHATTACHARYA et al. 1987; BROOKE et al 2010); b) the superficial zone of the deep weathering mantle of sub-aerial etchplains shows comparable elements that can be identified in the studied sub bottom (BROOKE et al. 2010; TAYLOR \& HOWARD 1998; DEMEK 2003; GUNNELL et al. 2007; ARAYA-VERGARA 2000); c) the tectonic control is considered (TAYLOR \& HOWARD 1998; DEMEK 2003); and d) the age of the deep weathering is taken into account (DUMONT 1991; TAYLOR \& HOWARD 1998: DEMEK 2003; ARAYAVERGARA 2000).

Then: a) the space between the bottom and sub bottom reflectors of Corcovado can be interpreted as a regolith of basement and the sub bottom reflector, as the corresponding weathering front; b) its sinking seems related with the regional system of faults; c) the Miocene age of the sub aerial weathering lapse of exposure indicates that the corresponding mantle pre-dates the etchplain sinking and that, consequently, the sub-bottom features represent a submerged etchplain surface; and d) a fundamental question is related with the lack of total stripping of the weathering mantle during the submersion; the corresponding response can be given only after the knowledge of some complex processes, exposed succinctly in the discussion.

\section{ACKNOWLEDGMENTS}

This study was supported by the Cimar 1-Fiordos program (Comité Oceanográfico Nacional). The survey of sub-bottom was possible thanks to the good work of the technical staff of the AGOR Vidal Gormaz. The corresponding acoustic records were well preserved for analysis by the Executive Secretary staff of the Comité Oceanográfico Nacional. The author thanks to the anonymous referees for the useful comments on the manuscript.

\section{REFERENCES}

ARAYA-VERGARA, J.F., 1997. Perfiles geomorfológicos de los fiordos y depresión longitudinal de Norpatagonia. Cienc. Tecnol. Mar, 20: 3-22.

ARAYA-VERGARA, J.F., 2000. Desarrollo de superficies de aplanamiento disectadas sobre coast range en la región del Maule, Chile Central. Invest. Geogr. Chile, 34: 77104.

ARAYA-VERGARA， J.F., 2008. The submarine geomorphology of the Chilean Patagonian fjords and piedmonts. In: Silva, N. \& S. Palma (Eds.), Progress in the oceanographic knowledge of Chilean interior waters, from Puerto Montt to Cape Horn. Comité Oceanográfico NacionalPontif. Univ. Catól. de Valparaíso, Valparaíso, pp.25-27.

BHATTACHARYA, G.C., F. ALMEIDA, K.H. VORA \& N.H. SIDIQUE, 1987. Subsurface geology off Bombay paleoclimatic interference interpreted from shallow seismic profiles. J. Coastal Res., 3(4): 521-530. 
BROOKE, B.P., C.D. WOOLROFFE, M. LINKLATTER, M.A. Mc ARTHUR, S.I. NICHOL et al., 2010. Geomorphology of the Lord Howe Island shelf and submarine volcano. Geoscience Australia. Australian Government, Marine Biodiversity Research, Univ. of Wollongong, SS06-2008, Post Survey Report, Record 2010/26, Camberra, $125 \mathrm{pp}$.

DAMUTH, J.E., 1978. Echo character of the Norwegian-Greenland Sea, relationship to Quaternary sedimentation . Mar. Geol., 28: 1-36.

DELGADO, S., 2004. Relación entre el perfil del basamento en fiordos y canales y la morfoestructura regional en Norpatagonia. Tesis de Magister en Geografía, Facultad de Arquitectura y Urbanismo, Universidad de Chile, Escuela de Post Grado, Santiago, 93 pp., inédita.

DEMEK, J., 2003. Etchplain, rock pediments, glacises and morphostructural analysis of the Bohemian Massif (Czech Relublic). Geomorfologický sbornik, 2: 215-221.

DUMONT, P., 1991. Problèmes de datation des surfaces d'aplanissement au Zaïre. Bull. Soc. Géogr. Liège, 27: 175-185. GUNNELL, Y., $\quad \begin{aligned} & \text { R. BRAUCHER, } \\ & \text { D. BOURLÈS \& }\end{aligned}$ G. ANDRÉ. 2007. Quantitative and qualitative insights into bedrock erosion on the South Indian craton using cosmogenic nuclides and apatite fission tracks. GSA Bull., 119(5-6): 576-585.

LIDMAR-BERGSTRÖM, K. \& J.M. BONOW, 2009. Hypotheses and observations on the origin of the landscapes of southern Norway-A comment regarding the isostasy-climate-erosion hypothesis by Nielsen et al. 2008. J. Geodyn., 48: 95-100.
NIELSEN, S.B., K. GALLAGHER, C. LEIGHTON, N. BILLING \& L. SVENNINGSEN et al., 2009. The evolution of western Scandinavian topography: A review of Neogene uplift versus the ICE (isostasy-climate-erosiom) hypothesis. J. Geodyn., 47: 72-95.

PRATSON, L.F. \& E.P. LAINE, 1989. The relative importance of gravity-induced versus current-controlled sedimentation during the Quaternary along the Mideast U.S. outer continental margin revealed by $3.5 \mathrm{kHz}$ echo character. Mar. Geol., 89: 87126.

RODRIGO, C., 2008. Submarine topography in the Chilean North Patagonian channels. In: Silva, N. \& S. Palma (Eds.), Progress in the oceanographic knowledge of Chilean interior waters, from Puerto Montt to Cape Horn. Comité Oceanográfico Nacional - Pontif. Univ. Catól. de Valparaíso, Valparaíso, pp. 19-23.

TAYLOR, R.G. \& K.W.F. HOWARD, 1998. Post-Palaeozoic evolution of weathered landsurfaces in Uganda by tectonically controlled deep weathering and stripping. Geomorphology, 25: 173-192.

THOMAS, M.J., 1994. Geomorphology in the Tropics. Wiley, Chichester.

VAN DER WAL, W., P. WU, H. WANG \& M.G. SIDERIS, 2010. Sea levels and uplift rate from composite rheology in glacial isostatic adjustment modeling. J. Geodyn., 50: 38-48. 


\section{Imagen de Investigaciones GEOGRAFICAS}

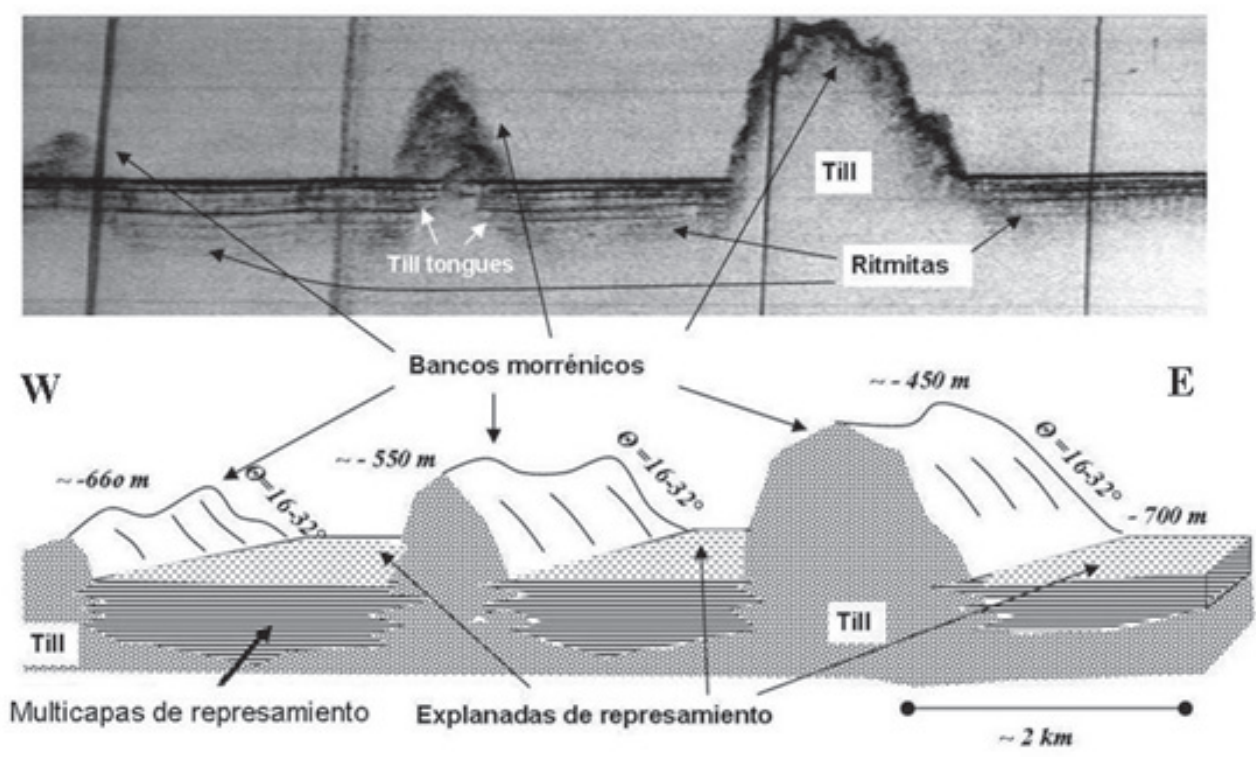

Fiordo Baker, zona externa: paisaje submarino del fondo y su morfoestructura

Fiordo Baker, Patagonia Central, zona externa: Registro obtenido con el perfilador de sub fondo Edo Western en frecuencia de $3.5 \mathrm{k} \mathrm{Hz}$, a bordo del buque de investigación AGOR Vidal Gormaz. Morfoestructura y geomorfología expresadas como paisaje submarino en bloque diagrama (J.F. Araya Vergara): Seascape en vez de landscape.

CInvestig. Geogr, Chile, todos los derechos reservados. 